\title{
Salivary Gland Sparing and Improved Target Irradiation by Conformal and Intensity Modulated Irradiation of Head and Neck Cancer
}

\author{
Avraham Eisbruch, M.D., ${ }^{1}$ Jonathan A. Ship, D.M.D., ${ }^{2}$ Laura A. Dawson, M.D., ${ }^{1}$ Hyungjin M. Kim, D.Sc., ${ }^{3}$ \\ Carol R. Bradford, M.D., ${ }^{4}$ Jeffrey E. Terrell, M.D., ${ }^{4}$ Douglas B. Chepeha, M.D., ${ }^{4}$ Theodore N. Teknos, M.D., ${ }^{4}$ \\ Norman D. Hogikyan, M.D., ${ }^{4}$ Yoshimi Anzai, M.D., ${ }^{5}$ Lon H. Marsh, R.T.T., ${ }^{1}$ Randall K. Ten Haken, Ph.D., ${ }^{\prime}$ \\ Gregory T. Wolf, M.D. ${ }^{4}$ \\ ${ }^{1}$ Department of Radiation Oncology, University of Michigan, 1500 Medical Center Drive, Ann Arbor, Michigan 48109, USA \\ ${ }^{2}$ New York University College of Dentistry, 345 East 24th Street, New York, New York 10010, USA \\ ${ }^{3}$ Department of Biostatistics, University of Michigan, 1500 E. Medical Center Drive, Ann Arbor, Michigan 48109, USA \\ ${ }^{4}$ Department of Otorhinolaryngology-Head and Neck Surgery, University of Michigan, 1500 Medical Center Drive, Ann Arbor, Michigan 48109, USA \\ ${ }^{5}$ Department of Radiology, University of Michigan, 1500 Medical Center Drive, Ann Arbor, Michigan 48109, USA
}

Published Online: June 3, 2003

\begin{abstract}
The goals of this study were to facilitate sparing of the major salivary glands while adequately treating tumor targets in patients requiring comprehensive bilateral neck irradiation (RT), and to assess the potential for improved xerostomia. Since 1994 techniques of target irradiation and locoregional tumor control with conformal and intensity modulated radiation therapy (IMRT) have been developed. In patients treated with these modalities, the salivary flow rates before and periodically after RT have been measured selectively from each major salivary gland and the residual flows correlated with glands' dose volume histograms (DVHs). In addition, subjective xerostomia questionnaires have been developed and validated. The pattern of locoregional recurrence has been examined from computed tomography (CT) scans at the time of recurrence, transferring the recurrence volumes to the planning CT scans, and regenerating the dose distributions at the recurrence sites. Treatment plans for target coverage and dose homogeneity using static, multisegmental IMRT were found to be significantly better than standard RT plans. In addition, significant parotid gland sparing was achieved in the conformal plans. The relationships among dose, irradiated volume, and the residual saliva flow rates from the parotid glands were characterized by dose and volume thresholds. A mean radiation dose of $26 \mathrm{~Gy}$ was found to be the threshold for preserved stimulated saliva flow. Xerostomia questionnaire scores suggested that xerostomia was significantly reduced in patients irradiated with bilateral neck, parotid-sparing RT, compared to patients with similar tumors treated with standard RT. Examination of locoregional tumor recurrence patterns revealed that the large majority of recurrences occurred inside targets, in areas that had been judged to be at high risk and that had received RT doses according to the perceived risk. Tangible gains in salivary gland sparing and target coverage are being achieved, and an improvement in some measures of quality of life is suggested by our findings. Additional reduction of xerostomia may be achieved by further sparing of the salivary glands and the non-involved oral cavity. A mean parotid gland dose of $\leq \mathbf{2 6} \mathbf{G y}$ should be a planning objective if significant parotid function preservation is desired. The pattern of recurrence suggests that careful escalation of the dose to areas judged to be at highest risk may improve tumor control.
\end{abstract}

Correspondence to: Avraham Eisbruch, M.D., e-mail: eisbruch@ umich.edu
The underlying goal in the development of conformal and static multisegmental intensity modulation (IMRT) techniques is to improve the ratio of target to normal tissue dose, and thereby to increase the probability of uncomplicated locoregional tumor control. In the treatment of head and neck cancer, we have made efforts to use these techniques to spare the major salivary glands while improving target irradiation.

The major salivary glands (parotid, submandibular, and sublingual) produce about $90 \%$ of the salivary secretions, and the minor salivary glands produce the remainder [1]. Of the major glands, the parotid glands contribute the most saliva during stimulation (e.g., eating or drinking). Standard radiation for advanced extracranial head and neck tumors typically involves administering radiation to the major salivary glands bilaterally. In most cases this causes a marked reduction in saliva output. Permanent xerostomia is the most prevalent late side effect of irradiation for head and neck malignancies and is cited by patients as a major cause of decreased quality of life [2-4]. In addition to its effects on subjective wellbeing, decreased saliva output causes alterations in speech and taste and difficulties with mastication and deglutition that create secondary nutritional deficiencies. Oral mucosal dryness creates a predisposition to fissures and ulcerations, and changes in the composition of the oral flora lead to dental caries and infections [5].

The treatment of radiation-induced salivary gland dysfunction and xerostomia has been unsatisfactory. Saliva substitutes are generally ineffective. Patients who have residual salivary function may benefit from stimulation of the glands by pilocarpine. but the sequelae from chronic use of this cholinergic agent may limit its usefulness [6]. The use of the radiation protector amifostine has been reported to result in salivary function improvement over time [7], and to have a significant protective effect on the salivary glands [8]. It requires intravenous (IV) drug infusions before each radiation fraction, increasing the cost and the logistic complexity of treatment. 
Since 1994, efforts at the University of Michigan to decrease xerostomia have concentrated on the use of conformal irradiation techniques to spare major salivary tissue. The ultimate goal of these efforts has been to achieve a significant improvement in patients' quality of life while adequately irradiating the targets.

\section{Patients and Methods}

The patients included in our studies of conformal radiotherapy (RT) and IMRT required comprehensive, bilateral neck irradiation. Had standard irradiation techniques been used in these patients, it would have encompassed most of both parotid glands within the radiation fields. Patients with oropharyngeal, hypopharyngeal, and oral cavity cancer, and patients with laryngeal cancer and clinical evidence of neck lymph node metastases were included.

Reliable immobilization of the head, neck, and shoulders becomes an essential component of planning and treatment, as patient set-up errors could lead to significant decreases in target dose and normal tissue sparing. To permit accurate set-up while permitting treatment access from most angles, an immobilization system has been developed, consisting of a custom thermoplastic mask attached to a foam cradle shaped to the patient's back and shoulders [9]. This system is used in our department for immobilization during the planning computed tomography (CT) scan and during treatment.

Magnetic resonance imaging (MRI) is performed without an immobilization system, and its images are registered with the planning CT images according to previously published methods [10]. Except for tumors near the base of skull, there is no clear evidence suggesting an additional benefit of MRI over CT in the determination of nodal involvement or tumor extent in the extracranial head and neck [11]. We therefore do not use MRI routinely in other tumor locations.

An accurate selection of the targets to be irradiated, especially targets that require elective treatment, and an accurate radiographic delineation of the extent of disease are critical steps in the planning of conformal RT. The targets are defined as "primary," including the primary tumor and lymph nodes with clinical or radiographic evidence of metastases, and "secondary," consisting of lymph node groups that are at risk of harboring subclinical metastases. Our choices of lymph node targets and the methods of their delineation on the axial planning CT images have been described elsewhere [12]. Of note, in the neck judged to be at lower risk (contralateral to the primary tumor and without clinical evidence of metastatic disease), the most cranial nodal group defined for adjuvant treatment is the jugulodigastric nodal group (extending cranially to the axial CT image in which the posterior belly of the digastric muscle crosses the jugular vein). In the neck at higher risk in the same patient (ipsilateral to the primary tumor or the neck containing clinically apparent metastases) the cranial-most jugular nodes are outlined up to the base of the skull in the poststyloid area. These adjuvant target definitions facilitated substantial parotid gland sparing in the neck at lower risk of metastases and were anticipated not to compromise tumor control, as most contralateral neck metastases are found in the jugulodigastric nodes [13].

Patients with nasopharyngeal cancer or patients with clinically apparent bilateral neck metastases require treatment of the jugular nodal chain through the base of skull bilaterally. In patients with oropharyngeal, hypopharyngeal, and nasopharyngeal cancer, the retropharyngeal nodes are defined as targets bilaterally.
The extent of subclinical disease in the vicinity of the gross tumor in each case is unknown. We therefore typically expand the gross target volume (GTV) of the primary tumor and lymph node metastases by 1 to $2 \mathrm{~cm}$, depending on the perceived risk at each site, to yield the clinical target volume (CTV), which accounts for microscopic tumor extension. Nodal groups at risk are also defined as CTVs. Three-dimensional expansions of the CTVs, to yield planning target volumes (PTVs), are made automatically by the planning system. In addition to the targets, noninvolved structures relevant to planning are outlined on the axial CT images, including the parotid, submandibular, and sublingual glands, as well as the laryngeal glottis, the spinal cord, and the oral cavity, to facilitate sparing and to assess the doses delivered to these structures.

Our methods for parotid gland sparing have evolved over time. Initially, a modification of the standard 3-field radiation technique was employed, using beam's eye view (BEV) displays of the targets and the major salivary glands to choose beam angles that would assure target coverage and spare parotid gland tissue [12]. Since 1996, IMRT has been used [14]. This method makes use of fixed field shaping to create intensity-modulated fields by adding the dose from several different-shaped segments delivered in the same direction. The development and detailed description of a typical plan have been published elsewhere [15]. The spinal cord maximal dose is constrained at $50 \mathrm{~Gy}$. This is a DVH-derived dose that includes all direct, scattered, and transmitted radiation. We have previously found that this dose in a three -dimensional conformal plan is comparable to the dose delivered to the spinal cord from standard opposed lateral fields that are blocked off-cord at 45 Gy [16].

Planning has until recently been a forward, iterative process. Recently, an automated optimization approach has been developed in our department [14]. It involves the use of "costlets" (individual components of the cost function) to describe the behavior of individual features of the desired solution [17] and the use of "beamlets" (distinct segments or a variable size grid of squares) to allow optimization based on dose distribution [18].

Measurements of salivary flow rate from each major gland are made before and periodically after radiation to verify the extent of functional sparing and to assess dose-volume-effect relationships. Unstimulated and stimulated saliva is collected from each parotid gland in a collecting cup placed over the orifice of the parotid (Stensen's) duct as described previously [19]. Repeated pre-RT saliva flow rate measurements found high inter-observer and intraobserver correlation coefficients [20].

The ultimate goal of these efforts to spare the salivary glands is to improve the quality of life for our patients. To this end, we have used several tools to assess xerostomia-related and general qualityof-life issues in patients treated with parotid-sparing techniques. The initial tool consisted of a panel of five questions that had been found by other investigators to correlate with objective salivary hypofunction [21]. As the study progressed it became apparent that this tool was not sensitive enough to detect subtle differences in xerostomia, so additional tools were developed. A questionnaire was developed from a previously published questionnaire [22] that was modified after our experience with patient symptoms. It consists of eight questions to which the answers are given in a numeric scale ranging from 0 (no dryness) to 10 (severe dryness). The questions probe the patients' rating of mouth dryness while not eating; dryness leading to problems with chewing, swallowing food, sleeping, and talking; discomfort of dentures; frequency of use of oral comfort aids; and frequency of fluid intake to aid eating. Tests of 
the reliability and validity of this tool were found to be satisfactory. In addition to the xerostomia-specific questionnaires, general quality of life is assessed by means of a validated tool developed at the University of Michigan that contains questions about the domains of pain, communication, eating, and emotions [23].

A crucial concern in this work is whether conformal and IMRT techniques, aimed at delivering radiation selectively to defined targets, compromise tumor control compared with standard radiation. To gain accurate data about the locoregional recurrence pattern and the doses delivered to the sites of recurrence, diagnostic CT scans were performed when recurrences occurred. The recurrent tumor volume was defined on the CT and transferred to the pretreatment CT data set used for radiation planning. The dose of radiation received by the volume of recurrence during RT could then be calculated and analyzed. Recurrences were categorized as being inside, at the margins, or outside the original target volumes ("in field" if $95 \%$ or more of the recurrence volume was encompassed by the full prescribed dose, "marginal" if $20 \%$ to $95 \%$ of the volume was encompassed, and "outside" if less than $20 \%$ of the recurrence volume lay within the full dose).

\section{Results}

The adequacy of target coverage by the multisegmental intensity modulation plans was assessed. Fifteen patients with stage III/IV head and neck cancer requiring comprehensive, bilateral neck irradiation were planned and treated with the IMRT techniques described above. For purposes of comparison, standard radiation fields were devised retrospectively for each patient, with the same CT-derived targets used for the IMRT plans [15]. On average, the minimal dose to the primary target volume in the conformal plans was significantly higher than that in the standard plans $(95 \%$ versus $91 \% ; p=0.02)$. Similar advantages of the conformal plans were found in the coverage of the jugular nodes. In the conformal plans, the magnitude and volumes of high doses in noninvolved tissue were significantly reduced. The mean doses to all major salivary glands, most notably the contralateral parotid (receiving on average $32 \%$ of the prescribed dose) were significantly lower in the conformal plans than they would have been with standard radiation plans. The mean dose to the noninvolved oral cavity also tended to be lower in the conformal plans $(p=0.07)$ [15].

The relationships between the three-dimensional dose distributions and the salivary output from parotid glands were recently examined [24]. Unstimulated and stimulated saliva flow rates from parotid glands of 88 patients were measured before RT and at 1, 3, 6 , and 12 months after the completion of RT. Glands receiving a mean dose below or equal to threshold (24 Gy for the unstimulated and 26 Gy for the stimulated saliva) showed substantial preservation of the flow rates after RT, and salivary flow continued to improve over time (to median $76 \%$ and $114 \%$ of the pre-RT rates for the unstimulated and stimulated flow rates, respectively, at 12 months). In contrast, most glands receiving a mean dose higher than the threshold produced little saliva and showed no recovery over time. Similarly, partial volume thresholds were found: $67 \%$, $45 \%$, and $24 \%$ gland volumes receiving more than $15 \mathrm{~Gy}, 30 \mathrm{~Gy}$, and $45 \mathrm{~Gy}$, respectively. Diminished salivary flow was observed in glands receiving each specified dose to a partial volume larger than the threshold.

To achieve bilateral parotid gland sparing treatment plans that meet our recently defined constraints arising from the saliva flow

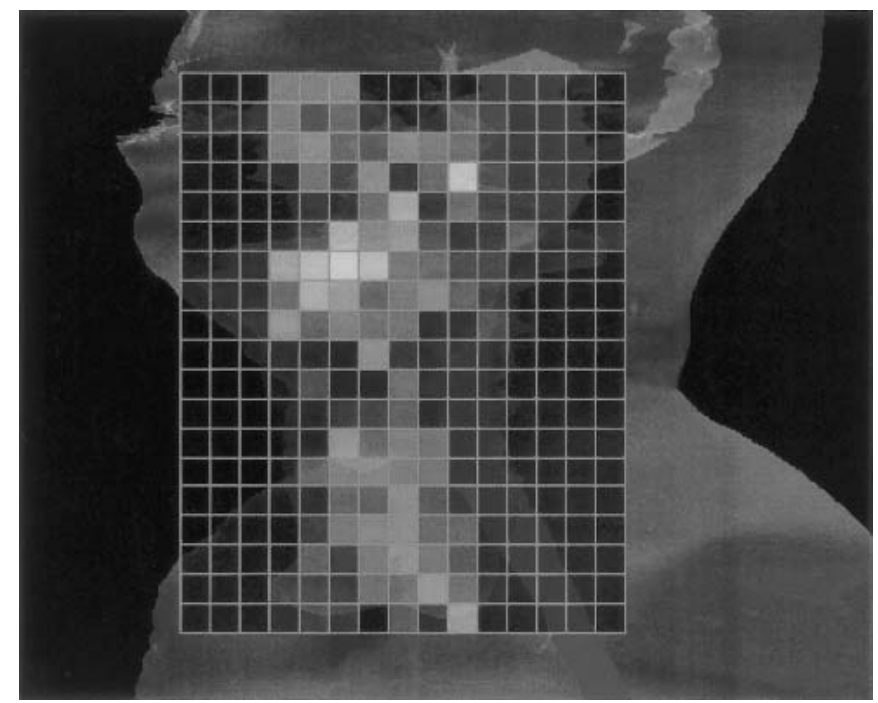

Fig. 1. "Beamlet" array $(1 \times 1 \mathrm{~cm}$ grid $)$ in a lateral field. The beamlet dose intensities are superimposed on the targets and normal structures (parotid gland, oral cavity, and spinal cord).

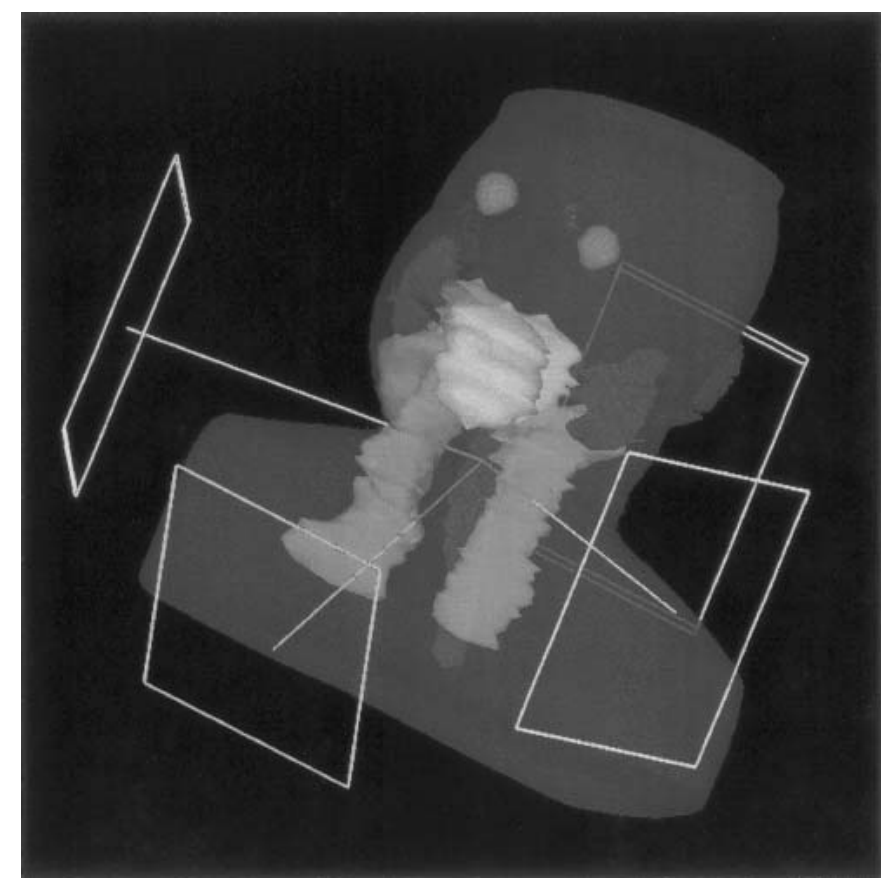

Fig. 2. An arrangement of three axial fields and an anterior-inferior field in the treatment planning for a patient with oropharyngeal cancer. Each field is composed of beamlets similar to the example shown in Figure 1.

study (mean dose $\leq 26$ Gy), investigations have begun that use the automated optimization system developed in our department.. Treatment plans employ beams that are divided into a grid of $1 \times 1$ cm "beamlets," each delivering an optimized dose intensity depending on whether targets or noninvolved tissues are in its path (Figs. 1 and 2). Preliminary results show that a plan consisting of three coplanar beams and an additional noncoplanar, anteriorinferior beam, produce dose distributions that cover the targets adequately and satisfy the dose constraints for the spinal cord and oral cavity in many patients. Such a plan also satisfies the dose constraints for both parotid glands (Fig. 3). 


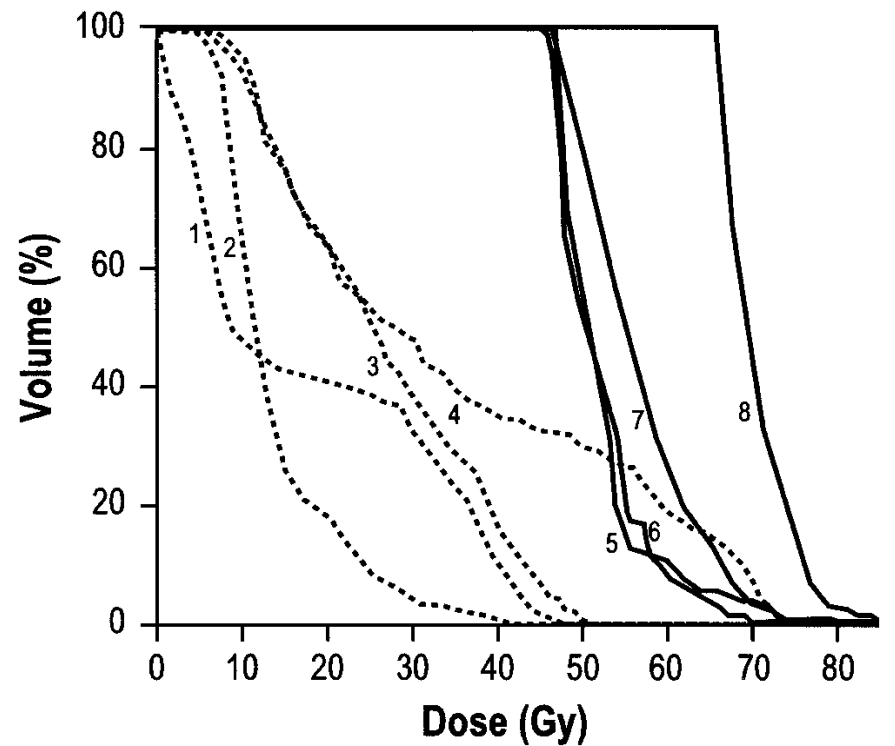

Fig. 3. Dose-volume histograms of the targets and uninvolved structures. The prescribed doses are 70 Gy to the primary tumor and $50 \mathrm{~Gy}$ to the nodal targets. Beam arrangement is described in Figures 1 and 2. 1: spinal cord; 2: left parotid; 3: right parotid; 4: uninvolved oral cavity; 5: left jugular nodes planning target volume (PTV); 6: right jugular nodes PTV; 7: retropharyngeal nodes PTV; 8: primary tumor PTV.

Subjective xerostomia scores using the eight-question validated questionnaire (described in Patients and Methods) were compared in a preliminary, nonrandomized study among groups of 17 patients who received bilateral neck, parotid-sparing RT at the University of Michigan (group 1), 13 similar patients who received standard RT in affiliated facilities (group 2), and 19 patients with smaller tumors who received unilateral neck RT (group 3) [25]. One year after the completion of RT, the mean xerostomia scores ( \pm S.D.) were $33 \pm 15,49 \pm 13$, and $15 \pm 14$, for groups 1,2 , and 3 , respectively (a higher score meaning worse xerostomia). The scores of patients receiving bilateral neck, parotid-sparing RT were significantly lower than the scores of patients receiving standard RT $(p=0.005)$. The scores of patients receiving unilateral neck RT were significantly lower than either group receiving bilateral neck RT. A simple relationship between the saliva output from the major salivary glands and the xerostomia scores was not found.

The pattern of locoregional tumor recurrenceafter comprehensive, parotid-sparing RT, was recently examined in all 58 patients treated in our department between April 1994 and June 1998. At a median follow-up of 27 months in patients who were still alive (range, 6 to 60 months), locoregional recurrences were observed in $12(21 \%)$ : local in 3, regional in 7, and synchronous local and regional in 2. Four of the regional recurrences occurred in the parapharyngeal and retropharyngeal nodal areas near the base of skull, ipsilateral to the primary tumor in patients with oral and oropharyngeal primary tumors. Three of the recurrences near the base of skull were in-field, in areas that had received the prescribed dose for subclinical disease (50-60 Gy), and one was a marginal recurrence. Overall, 10 of the 12 recurrences were in-field, in areas judged to be at high risk, and 2 were marginal recurrences. No recurrences were observed in the parapharyngeal areas near the base of the skull contralateral to the primary tumor, areas that were spared during RT planning.

\section{Discussion}

The results of our studies of saliva flow versus dose and volume of irradiated parotid glands based on DVHs suggest that dosevolume-function relationships are characterized by dose and volume thresholds, and by steep dose-response relationships when the thresholds have been reached. A parotid gland mean dose of 26 Gy was found to be a threshold for the stimulated saliva flow. This mean dose serves now as a planning objective for the parotid glands. Similar dose thresholds have been found by other investigators using standard RT [26], and higher doses were found by others $[27,28]$. Previous attempts to relate dose and effect relationships in the salivary glands relied on estimations of the dose and irradiated gland volumes based on the simulation films, estimations that are fraught with uncertainty. Also, the use of standard RT in the previous studies (usually lateral opposed beams) limited the range of RT doses and irradiated gland volumes, diminishing the investigators' ability to assess dose-response relationships over a wide range of doses and irradiated gland volumes.

Preliminary results of xerostomia-related quality-of-life studies suggest a significant improvement in patients treated with parotidsparing techniques compared with patients with similar cancer receiving standard RT. Our results, however, also showed that patients receiving unilateral neck RT fared better, in terms of their symptoms, than patients receiving parotid-sparing bilateral neck RT. These findings suggest that further improvements in major salivary gland and oral cavity sparing can be expected to result in still better quality-of-life measures.

Of the issues we have encountered and described in this article, the choice and adequate radiologic definition of the targets are arguably the most perplexing and important. It has previously been shown that definition of head and neck nodal volumes varies significantly among different experienced radiologists [29, 30]. The need for adequate anatomic definitions of the targets is a prerequisite for accurate conformal RT planning and for adequate tumor control. Steps toward accurate and reproducible descriptions of radiologic target definitions in the head and neck for radiation planning have recently been made $[31,32]$. Insight into this issue may be gained from a careful analysis of the pattern of recurrences relative to the targets outlined and the doses received during treatment. In our study, the large majority of recurrences thus far have occurred in-field, in areas judged to be at high risk, having received the full prescribed dose. This pattern is similar to the pattern of locoregional recurrence observed after standard, three-field RT [33]. This finding highlights the possibility that carefully designed dose escalation to the highest risk targets, using conformal techniques with tight dose margins, may improve tumor control without increasing complications. The most important question surrounds the rates of tumor control after IMRT compared to the rates observed after standard RT. The answer can only be given by large, randomized, multi-institutional studies. Such trials are required to assess the extent to which these new, labor-intensive and costly techniques serve to improve quality of life while preserving or improving tumor control rates beyond the results achieved with standard radiation.

Résumé. Le but de cette étude a été, chez les patients nécessitant une radiothérapie bilatérale du cou (RT), de développer des techniques facilitant la conservation des glandes salivaires majeures tout en traitant de façon efficace les cibles souhaitées et également, d'évaluer la possibilité de reduire la fréquence de xérostome et d'améliorer l'irradiation au niveau de la cible et ainsi le contrôle locorégional de la tumeur. Des techniques 
conformes comportant avec modulation d'intensité (IMRT) ont été développés depuis 1994. Chez les patients traités ainsi, on a mesuré sélectivement, les débits avant et, de façon périodique, après RT, à partir de chaque glande salivaire majeure. Les débits résiduels ont ensuite été corrélés avec les histogrammes dose/volume (DVHs). Un questionnaire subjectif sur la xérostome a été développé et validé. La topographie des récidives locorégionales a été évaluée par tomodensitométrie au moment de la récidive, avec transfert des volumes de récidives pour adapter et redistribuer les doses au niveau des sites des récidives. La couverture des cibles et l'homogénéité des doses délivrées ont été améliorées par le traitement par IMRT multisegmentaire poar rapport aux plans de coupes standard de RT. La conservation de la glande parotide a été significativement augmentée dans les plans dits de conformité. Les rapports entre les doses, le volume irradié et les débits résiduels de salive des glandes parotides ont été caractérisées par des valeurs seuils de dose et de volume. La valeur seuil pour conserver un débit salivaire stimulé. Les scores du questionnaire de xérostome ont suggéré que la fréquence de xérostome a été significativement réduite chez les patients traités par une RT cervicale bilatérale visant à conserver la parotide, comparé aux patients porteurs de tumeurs similaires traités par une RT standard. L'analyse de la topographie des récidives tumorales loco-régionales a montré que la plupart des récidives se sont produites à l'intérieur des cibles, dans les régions estimées être à haut risque et qui ont été irradiées selon le risque perçu. On a pu ainsi obtenir un gain considérable en ce qui concerne la conservation glandulaire et la couverture des cibles. Nos données suggèrent une amélioration de la qualité de vie selon certains critères: réduction supplémentaire de la fréquence de xérostomes, conservation des glandes salivaires et de la cavité buccale saine. Il faut donc envisager une dose moyenne de 26 Gy ou moins sur la glande parotide pour pouvoir espérer une conservation de la fonction de la parotide. La topographie des récidives suggère qu'une augmentation soigneuse des doses dans les régions estimées être à risque élevé pourrait améliorer le contrôle tumoral.

Resumen. El propósito del presente estudio es desarrollar una técnica que facilite preservar las glándulas salivares principales al tiempo que se traten los volúmenes blanco (targets) en pacientes que requieran irradiación bilateral comprensiva (RT), y evaluar el potencial de mejoría de la xerostomia, la irradiación del volumen blanco y el control local-regional del tumor. A partir de 1994 se han desarrollado técnicas conformales y de intensidad modulada (TCIM). En los pacientes así tratados se hizo la medición selectiva de las tasas de flujo salivar de cada glándula antes de la RT y periódicamente luego de completar la RT, para correlacionar los flujos residuales con los histogramas de volumen-dosis. Se desarrollaron y valoraron cuestionarios de xerostomia. Se estudió el patrón de las recurrencias locales-regionales por medio de TAC en el momento de la recurrencia, para transferir los volúmenes de la recurrencia a los TACS de simulación y para regenerar así la distribución de la dosis en los lugares de la recurrencia. Tanto el cubrimiento del volumen blanco como la homogeneidad en los planes de tratamiento utilizando TCIM multisegmentario estático resultaron significativamente mejores que los planes de RT estándar. Además, con los planes conformales se logró una significante preservación de la glándula parótida. La relación entre dosis, volumen irradiado y las tasas de flujo salivar residual de las glándulas parótidas se caracterizaron por los umbrales de dosis y volumen. Se encontró que una dosis promedio de 26 Gy era el umbral para preservar el flujo salivar estimulado. Los resultados del cuestionario de xerostomia sugieren que la xerostomia se redujo en forma significante en los pacientes que recibieron RT bilateral con preservación de la parótida, en comparación con pacientes con tumores similares tratados con RT estándar. El análisis de los patrones de recurrencia tumoral local regional reveló que la gran mayoría de las recurrencias ocurrió dentro de las áreas de volumen blanco, en zonas que habían sido consideradas como de alto riesgo y que habían recibido dosis de RT según la percepción del riesgo. Progresos tangibles han sido logrados en cuanto a la preservación de las glándulas salivares y de cobertura del área de volumen blanco, al tiempo con una mejoría en la calidad de vida, a juzgar por nuestros hallazgos. Se puede lograr una reducción adicional de la xerostomia mediante mayor preservación de las glándulas salivares y de las regiones no afectadas de la cavidad oral. Una dosis promedio de $\leq \mathbf{2 6}$ Gy debe ser el objetivo de la planeación si se pretende conservar una función parotídea significante. El patrón de recurrencia sugiere que la cuidadosa escalada de la dosis en áreas que se consideren de alto riesgo puede mejorar el control tumoral.

\section{Acknowledgments}

This work was supported in part by National Institutes of Health grant CA78165.

\section{References}

1. Cooper JS, Fu K, Marks J, et al. Late effects of radiation therapy in the head and neck region. Int. J. Radiat. Oncol. Biol. Phys. 1995;31:11411164

2. Harrison LB, Zelefski MJ, Pfitzer DG, et al. Detailed quality of life assessment in patients treated with primary radiotherapy for cancer of the base of tongue. Head Neck 1997;19:169-175

3. Bjordal K, Kaasa S, Mastekaasa A. Quality of life in patients treated for head and neck cancer: a follow up study 7 to 11 years after radiotherapy. Int. J. Radiat. Oncol. Biol. Phys. 1994;28:847-856

4. Jensen $A B$, Hanse $\mathrm{O}$, Jorgensen $\mathrm{K}$, et al. Influence of late side-effects upon daily life after radiotherapy for laryngeal and pharyngeal cancer. Acta Oncol. 1994;33:487-491

5. Beeken L, Calman F. A return to normal eating after curative treatment for oral cancer: long term prospects. Oral Oncol. Eur. J. Cancer 1994;6:387-392

6. Johnson JT, Ferretti GA, Nethery WJ. Oral pilocarpine for postirradiation xerostomia in patients with head and neck cancer. N. Engl. J. Med. 1993;329:390-395

7. McDonald S, Meyerowitz C, Smudzin T, et al. Preliminary results of a pilot study using WR-2721 before fractionated irradiation of the head and neck to reduce salivary gland dysfunction. Int. J. Radiat. Biol. 1994; 29:747-754

8. Brizel D, Sauer R, Wannemacher M, et al. Randomized phase III trial of radiation + Amifostine in patients with head and neck cancer. Int. J. Radiat. Oncol. Biol. Phys. 1998;42:224

9. Marsh R, Balter J, Evans VL, et al. Design and analysis of an immobilization and repositioning system for treatment of neck malignancies. Med. Dosimetry 1997;22:293-297

10. Ten Haken RK, Thornton AF, Sandler HM, et al. A quantitative assessment of the addition of MRI to CT-based, 3-D treatment planning of brain tumors. Radiother. Oncol. 1992;25:121-133

11. Mancusso AA. Imaging in patients with head and neck cancer. In Million RR, Cassisi NJ, editors, Management of Head and Neck Cancer Philadelphia, JB Lippincott, 1994;43-59

12. Eisbruch A, Ship JA, Martel MK, et al. Parotid gland sparing in patients undergoing bilateral head and neck irradiation: techniques and early results. Int. J. Radiat. Oncol. Biol. Phys. 1996;36:469-480

13. Million, RR, NJ, Cassisi, Mancuso, AA et al. Management of the neck for squamous cell carcinoma. In Million, RR, Cassisi, NJ, editors, Management of Head and Neck Cancer, 2nd edition, Philadelphia, JB Lippincott, 1994;101

14. Fraas BA, Marsh LM, Watson BA, et al. Optimization and clinical use of multisegment intensity modulation for high dose conformal therapy. Semin. Radiat. Oncol. 1999;9:60-77

15. Eisbruch A, Marsh LH, Martel MK, et al. Comprehensive irradiation of head and neck cancer using conformal multisegmental fields: assessment of target coverage and noninvolved tissue sparing. Int. J. Radiat. Oncol. Biol. Phys. 1998;41:559-568

16. Martel MK, Eisbruch A, Lawrence TS, et al. Cord dose from standard head and neck treatments: implications for conformal treatment plans. Radiother. Oncol. 1998;47:185-189

17. Kessler ML, Kim JJH, McShan DL. A general framework for interactive and automated treatment plan optimization: part I. Evaluators, modifiers, and costlets. Med. Phys. 1998;25:118

18. McShan DL, Fraas BA, Kessler ML. Intensity modulation using beamlets. Med. Phys. 1998;25:149

19. Ship JA, Fox PC, Baum BJ. How much saliva is enough? Normal function defined. J. Am. Dent. Assoc. 1991;122:63-69

20. Jones RE, Takeuchi T, Eisbruch A, et al. Ipsilateral parotid sparing study in head and neck cancer patients receiving radiation therapy. Oral Surg. Oral Med. Oral Pathol. Oral Radiol. Endod. 1996;81:642-648

21. Fox PC, Busch KA, Baum BJ. Subjective reports of xerostomia and objective measure of salivary gland performance. J. Am. Dent. Assoc. 1987;115:581-584

22. Zimmerman RP, Mark RJ, Tran LM, et al. Concomitant pilocarpin 
during head and neck irradiation is associated with decreased posttreatment xerostomia. Int. J. Radiat. Onco. Biol. Phys. 1997;37:571-575

23. Terrell JE, Nanavati KA, Esclamado RM, et al. Head and neck cancer specific quality of life: Instrument validation. Arch. Otolaryngol. Head Neck Surg. 1997;123:1125-1132

24. Eisbruch A, Kim HM, Ten Haken R, et al. Dose, volume and function relationships in parotid glands following conformal and intensity modulated irradiation of head and neck cancer. Int. J. Radiat. Oncol. Biol. Phys. (in press)

25. Eisbruch A, Terrell J, Kim M, et al. Assessment of xerostomia -related quality of life in head and neck cancer patients receiving comprehensive radiation using parotid sparing techniques. Head Neck 1998;20:452

26. Leslie MD, Dische S. The early changes in salivary gland function during and after radiotherapy given for head and neck cancer. Radiother. Oncol. 1994;30:26-32

27. Marks JE, Davis CC, Gottsman VL, et al. The effects of radiation on parotid salivary function. Int. J. Radiat. Oncol. Biol. Phys. 1981;7:10131019
28. Franzen L, Funegard U, Ericson T, et al. Parotid gland function during and following radiotherapy of malignancies in the head and neck: a consecutive study of salivary flow and patient discomfort. Eur. J. Cancer 1992;28:457-462

29. Rasch C, Keus R, Pameijer FA, et al. The potential impact of CT-MRI matching on tumor volume delineation in advanced head and neck cancer. Int. J. Radiat. Oncol. Biol. Phys. 1997;39:841-848

30. Nowak P, van Dieren E, van der Est H, et al. Treatment portals for elective radiotherapy of the neck: an inventory in the Netherlands. Radiother. Oncol. 1997;43:81-86

31. Nowak P. Elective irradiation of the neck: a three dimensional CT definition of the target for conformal radiotherapy, Doctoral Thesis. Dr. Daniel van Hoed Cancer Center, Erasmus University, Rotterdam, the Netherlands, 1997

32. Hayman LA, Taber KH, Diaz-Marchan PJ, et al. Spatial compartments of the neck. Int. J. Neuroradiol. 1998;4:233-239

33. Pigott K, Dische S, Saunders MI. Where exactly does failure occur after radiation in head and neck cancer? Radiother. Oncol. 1995;37:17-19 